\title{
Cultura material e identidade étnica na arqueologia brasileira: um estudo por ocasião da discussão sobre a tradicionalidade da ocupação Kaiowá da terra indígena Sucuri’y
}

\author{
Jorge ERemites De OLIVEIRA*
}

\begin{abstract}
Resumo: Neste artigo, o autor apresenta uma análise geral sobre a analogia direta entre cultura material e identidade étnica na arqueologia brasileira. Analisa de modo específico a associação entre populações portadoras da tradição Tupiguarani, assim definida na época do Programa Nacional de Pesquisas Arqueológicas (Pronapa, 1965-1970), e grupos étnicos lingüisticamente ligados ao tronco tupi. Para esses grupos, tem sido atribuída uma identidade ou etnicidade genérica de "guarani". O referido problema é discutido com mais profundidade por ocasião da apreciação de um laudo pericial sobre a terra indígena Sucuri'y, localizada no município de Maracaju, no estado de Mato Grosso do Sul. No laudo analisado, a associação entre cultura material e identidade étnica remete ao debate a respeito do direito à terra por parte de uma comunidade indígena. Durante o estudo elaborado, o autor questiona os resultados finais da perícia produzida para a justiça federal e argumenta que existem evidências que sustentam a tese de que aquela área é, de fato, tradicionalmente ocupada pelos Kaiowá, de acordo com o que determina o Artigo 231 , $1^{\circ}$, da Constituição Federal de 1988.
\end{abstract}

Palavras-chave: arqueologia brasileira; identidade étnica; índios Kaiowá.

A associação direta entre uma cultura material do período pré-colonial com a identidade étnica de grupos conhecidos etnográfica e/ou historicamente tem sido bastante comum ao longo da história da arqueologia brasileira. Salvo melhor juízo, essa tendência se acentuou no país por conta das influências teórico-metodológicas difundidas a partir do Programa Nacional de Pesquisas Arqueológicas (Pronapa), desenvolvido entre 1965 e 1970, sob a coordenação de Betty J. Meggers e Clifford Evans, da Smithsonian Institution, de Washington, Estados Unidos. Daquela época até os dias de hoje, muitos

\footnotetext{
* Pesquisador do Laboratório de Arqueologia, Etnologia e História Indígena da Faculdade de Ciências Humanas, Universidade Federal da Grande Dourados - UFGD. E-mail: eremites@ufgd.edu.br.
}

trabalhos foram e seguem sendo produzidos, sob diferentes formas, a partir de uma perspectiva que conjuga abordagens histórico-culturais com técnicas, métodos e teorias difundidos posteriormente no país, principalmente a partir da década de 1980, a exemplo dos recorridos na arqueologia processual (Nova Arqueologia) e na pós-processual.

Muitos trabalhos que assumiram essa perspectiva buscaram a sistematização de uma gama considerável de dados empíricos, em geral na tentativa de produzir sínteses regionais, rever certos paradigmas e propor novos modelos interpretativos. Em casos assim, o diálogo interdisciplinar tem sido bastante profícuo. Refiro-me, por exemplo, ao uso da arqueologia como forma de perceber a história indígena e ao diálogo com 
a antropologia histórica, com a história cultural e com a etnoistória. ${ }^{1}$

Experiências desse tipo não podem ser desprezadas, tampouco serem alvo de críticas caricaturais sem que se faça uma análise apurada sobre o assunto. Não obstante esta realidade e longe de querer apresentar uma revisão exaustiva sobre o tema, entendo que o maior problema de muitos estudos está na associação direta entre tradições e estilos ceramistas com grupos étnicos identificados a partir de registros textuais incompletos, produzidos desde o início da conquista ibérica nas Américas.

O caso mais conhecido parece estar ligado à interpretação da trajetória de grupos étnicos vinculados ao tronco lingüístico tupi, à família lingüística tupi-guarani (com hífen) e à língua guarani, para os quais segue sendo atribuída uma identidade ou etnicidade genérica denominada guarani. Em situações desse tipo, uma tradição tecnológica ceramista, como a denominada na arqueologia brasileira de Tupiguarani (sem hífen), tem sido diretamente associada aos falantes de uma língua indígena, a guarani. ${ }^{2}$ A partir desses dois elementos (tradição ceramista e língua nativa), muitos arqueólogos têm freqüentemente identificado, de um ponto de vista etic e não emic, vários grupos étnicos como sendo "Guarani".

Nessas associações não raramente mudanças socioculturais decorrentes dos contatos entre os grupos étnicos, e entre eles e os europeus e euro-americanos, têm sido pouco enfatizadas ou praticamente ignoradas. Isso também decorre de uma leitura sincrônica e homogeneizante de dados etnográficos, lingüísticos e históricos produzidos desde tempos coloniais, o que dificulta a percepção dos intercâmbios e das trocas cultu-

\footnotetext{
1. Em língua portuguesa, a palavra etnoistória também pode ser grafada com hífen e "h" (etno-história), de modo semelhante à grafia em espanhol ("etnohistoria"), que é feita sem hífen e acento agudo, conforme consta nos trabalhos de Eremites de Oliveira (2003b) e Alves da Silva \& Eremites de Oliveira (2005).

2. O termo tupi-guarani, grafado com hífen, refere-se a uma família lingüística. Valendo-se da analogia histórica direta, uma tradição tecnológica ceramista foi definida com o mesmo nome durante a realização do Pronapa, porém sendo grafada sem hífen (Tupiguarani) para evitar o inevitável: a confusão entre tradição arqueológica, família lingüística e identidade étnica.
}

rais que ocorreram entre grupos étnicos cultural ou geograficamente próximos.

Um dos estímulos a essas analogias partiu da tese de doutorado de José Joaquim Justiniano Proenza Brochado, intitulada An ecological model of the spread of pottery and agriculture into eastern South America, defendida em 1984. Este trabalho foi apropriadamente considerado por Pedro Paulo A. Funari et al. (1999, p. 1) como a "síntese mais genial" já feita por um arqueólogo brasileiro, embora infelizmente ela não tenha sido traduzida para o português e publicada no país. Brochado assim afirmou em uma célebre frase bastante conhecida e reproduzida por muitos de nós:

Portanto, a primeira coisa que considerei aqui é que a arqueologia do leste da América do Sul deve ser vista como a pré-história das populações indígenas históricas e atuais. Se não forem estabelecidas relações entre as manifestações arqueológicas e as populações que as produziram, o mais importante terá se perdido. Assim as conotações etnográficas das tradições e estilos cerâmicos não devem ser evitadas, mas, pelo contrário, deliberadamente perseguidas. (Brochado, 1984, p. 565)

A proposta do autor remete à idéia de uma arqueologia como forma de perceber a história indígena, conforme apontado anteriormente. Nessa perspectiva, a trajetória dos grupos étnicos pré-coloniais, portadores de tecnologias ceramistas identificadas na arqueologia, teria uma continuidade histórica e cultural em tempos coloniais ou até mesmo nos dias de hoje. Sem levar em conta esse paradigma, "o mais importante terá se perdido", ou seja: (1) a possibilidade de um diálogo mais estreito entre arqueologia, etnologia e etnoistória, não apenas para apontar continuidades ou permanências, mas também descontinuidades e mudanças socioculturais, e (2) as vantagens de se ter um corpus de dados etnográficos e etnoistóricos para a formulação de modelos arqueológicos relevantes para a interpretação do passado pré-colonial. Em sua opinião, portanto, as analogias entre grupos étnicos atuais e tradições e estilos cerâmicos devem ser "deliberadamente perseguidas", sobretudo do ponto de vista da funcionalidade das vasilhas cerâmicas. 
O maior problema de sua proposta consiste, nos dias de hoje, no estímulo ao uso deliberado de analogias históricas diretas entre tecnologias ceramistas do passado pré-colonial e grupos étnicos conhecidos na etnologia. A situação é mais bem observada na vinculação da tradição ceramista Tupiguarani, assim definida no âmbito do Pronapa, como explicado anteriormente, com grupos étnicos da família tupi-guarani. Neste caso em particular, língua e cerâmica são apontadas como elementos que identificariam grupos étnicos de língua guarani nas chamadas terras baixas da América do Sul. O modelo apresentado desconsidera a auto-identificação dos grupos e o fato de eles terem diferentes formas de organização de sua cultura. Estas são duas questões relevantes para a percepção da identidade ou da etnicidade dos grupos étnicos, sobretudo se levados em conta os aportes de Fredrik Barth (1998 [1969]), autor da clássica "Introdução" aos Grupos étnicos e suas fronteiras, dentre outras obras, e de Sian Jones (1997), autora de The archaeology of ethnicity. Constructing identities in the past and present.

Desde a divulgação da tese de Brochado (1984), muitos modelos interpretativos foram revistos e outros tantos propostos para repensar a tradição Tupiguarani. Há uma bibliografia básica e uma discussão interessante sobre o assunto nos trabalhos de Francisco S. Noelli (1993, 1999/2000), Noelli et al. (1996), André Luis R. Soares $(1997,2003)$ e Solange N. de Oliveira Schiavetto (2003).

Em seu tempo, o macromodelo construído por Brochado serviu para explicar, dentre outras coisas, as prováveis rotas de deslocamento e expansão territorial de grupos étnicos lingüisticamente filiados ao tronco tupi e à família tupiguarani. Esses grupos, na condição de agricultores (ou horticultores, quer dizer, "agricultores incipientes", como preferem alguns) e ceramistas, teriam partido da Amazônia para ocupar outras áreas mais ao sul e a leste do subcontinente. A partir de seus estudos, trajetórias nativas milenares vêm sendo revistas e deliberadamente reconstituídas. Exemplo disso pode ser constatado em trabalhos bem-sucedidos como o dossiê Antes de Cabral: arqueologia brasileira, organizado por Walter Alves Neves (1999/2000), Pré-história da Terra Brasilis, organizado por Maria Cristina Tenório (1999), e Pré-história do Brasil, de Pedro Paulo Funari \& Francisco S. Noelli (2002), dentre outras publicações mais recentes.

Diante dessa situação, acredito ser necessário analisar criticamente o uso de analogias históricas na arqueologia brasileira, o que por vezes ocorre em desconsideração às diferenças étnicas e aos processos de mudança sociocultural, conforme dito amiúde. Uma discussão desse nível chama a atenção, ainda, para novos problemas relacionados ao uso dessas abordagens em situações que envolvem a reivindicação de direitos por parte de comunidades indígenas. Este último assunto foi o que mais me motivou a escrever este trabalho, cujas discussões foram levadas a público durante o XIII Congresso da Sociedade de Arqueologia Brasileira, ocorrido em Campo Grande, em setembro de 2005, e na $25^{\mathrm{a}}$ Reunião Brasileira de Antropologia, realizada em Goiânia, em junho de 2006.

A questão que mais tem me intrigado ultimamente diz respeito à atribuição de uma identidade étnica "Guarani" à cerâmica da tradição Tupiguarani que ocorre na região platina, assim como uma identidade homônima que antropólogos, arqueólogos e historiadores vêm sistematicamente atribuindo aos Chiriguano, Ñandeva, Mbyá e Kaiowá. Em Mato Grosso do Sul, por exemplo, apenas os chamados Ñandeva se auto-identificam como Guarani, conforme discutido na recente tese de doutorado de Beatriz dos Santos Landa (2005). Os Kaiowá que vivem no Brasil, por seu turno, se autoidentificam como Kaiowá, e não raramente explicitam sua identidade aos mais desavisados que se referem a eles como Guarani. No Paraguai, por outro lado, eles se autodenominam PaiTaviterã, segundo consta no clássico Etnografía guaraní del Paraguay contemporáneo: los Pai-Tavyterã, de Bartomeu Melià et al. (1976). Mas há, certamente, muitas semelhanças em comum entre esses quatro grupos, o que não sustenta a atribuição, de nossa parte, desta ou daquela identidade a eles, em desconsideração à sua autodenominação étnica, ou seja, ao seu etnônimo. Talvez a maior semelhança entre eles esteja mais no plano cosmológico e religioso, segundo apontaram Eduardo Viveiros de Castro (1987) e Levi Marques Pereira (2003), 
do que propriamente na organização social, na adaptação ecológica ou na cultura material, contrariando o que muitos arqueólogos e etnoistoriadores propuseram.

Entendo que o termo guarani vem sendo usado, desde tempos coloniais, para se referir a um Guarani genérico, "de papel", assim criticado por Maria Cristina dos Santos (1999). ${ }^{3}$ No entanto, esse mesmo Guarani tem sido de grande utilidade para a confecção de colchas de retalhos etnográficos ou para a construção de um "monstro" do tipo Frankenstein, conforme apontou Soares (2003), com o propósito de formular modelos interpretativos globalizantes, de longo alcance e ambiciosos em termos de abrangência espaço-temporal. Para essa tarefa, alguns arqueólogos têm atribuído um incomensurável valor etnográfico às obras Vocabulário de la lengua guaraní (1640) e Arte de la lengua guaraní (1640), do padre jesuíta Antonio Ruiz de Montoya, ${ }^{4}$ produzidas no século XVII, como se elas equivalessem aos Argonautas do Pacífico Ocidental, de Bronislaw Malinowski, publicado em 1922, ou mesmo a alguma obra desse nível produzida mais recentemente. Não se trata aqui de desmerecer o valor desses trabalhos, pelo contrário. Acredito, porém, que em alguns casos as obras de Montoya não têm merecido a devida apreciação crítica e a necessária relativização, como, aliás, convém fazer a qualquer fonte textual analisada para a construção de modelos interpretativos nas áreas de arqueologia, etnologia e etnoistória. Essa situação parece estar relacionada, também, à pouca experiência em pesquisa etnográfica que alguns arqueólogos necessitariam ter com grupos étnicos de língua guarani, algo que seria rele-

\footnotetext{
3. Nesse trabalho, a autora fez algumas apreciações inconsistentes e pouco elegantes em relação à obra da antropóloga de origem eslovena Branislava Susnik, ex-diretora do Museu Etnográfico Andrés Barbero, de Assunção, Paraguai, falecida em 1996. Algumas de suas apreciações foram por mim refutadas em um ensaio elaborado em 2003 e publicado naquele país (ver Eremites de Oliveira, 2003a).

4. Ver, por exemplo, as seguintes publicações de Antonio Ruiz de Montoya: (1) Montoya, A. R. de 2002. Vocabulário de la lengua guaraní (1640). Transcrição e transliteração de Antonio Caballos. Introdução de Bartomeu Melià Asunción: Cepag, 407p. (2) Montoya, A. R. 1993. Arte de la lengua guaraní (1640). Edição fac-similar. Transcrição de Antonio Caballos. Introdução de Bartomeu Melià. Asunción: Cepag, 307p.
}

vante para fazer uma leitura mais crítica e relativista em relação às duas obras mencionadas.

Exemplo disso por ser observado no uso exagerado que se tem feito de palavras em guarani para a criação de modelos referentes à subsistência, ao sistema de assentamentos, ao território e à organização social dos grupos étnicos que têm nesse idioma sua língua materna. Como ocorre entre muitos grupos sul-americanos, uma mesma espécie de planta ou animal pode ter duas ou mais denominações na taxonomia indígena. Uma realidade assim pode levar um pesquisador menos familiarizado com a observação participante, e valendo-se da taxonomia utilizada na biologia moderna, a interpretar uma única espécie como sendo várias. Situação semelhante se verifica com palavras polissêmicas como o termo tekoha, o qual tem sido mais empregado no sentido físico de território e menos usado como rede dinâmica de relações sociais que ocorre em determinado espaço geográfico (ver discussão em Noelli, 1993; Mura, 2004; Pereira, 2004). O problema se torna ainda mais complexo se consideradas as variações dialetais entre os grupos de língua guarani, algo que inclusive foi observado pelo referido padre da Companhia de Jesus. Neste sentido, parafraseando Viveiros de Castro (1987, p. xxii), autor do prefácio de Lendas da criação e destruição do mundo como fundamentos da religião dos Apapocúva-Guarani, de Curt Nimuendaju Unkel (1987), diria que essa questão lembra o "etimologismo" que, "diga-se de passagem, é endêmico nos arraiais da tupinologia".

De todo modo, os valorosos esforços de alguns colegas em prosseguir e ir mais além com o paradigma de Brochado (1984, p. 565), apresentado no início deste artigo, têm culminado na elaboração de trabalhos brilhantes sobre os Guarani genéricos. Obras como a de Noelli (1993), Sem tekohá não há teko: em busca de um modelo etnoarqueológico da aldeia e da subsistência guarani e sua aplicação a uma área de domínio no delta do Rio Jacuí$R S$, e a de Soares (1987), Guarani: organização social e arqueologia, são importantíssimas para a arqueologia brasileira e por isso as críticas aqui apresentadas não devem ser vistas como alguma forma de depreciação caricatural. A monografia produzida por Noelli (1993), por 
exemplo, é a melhor dissertação de mestrado já feita por um arqueólogo brasileiro, um trabalho de fôlego que sem dúvida alguma equivale ou supera muitas importantes teses de doutorado defendidas em universidades do país e do exterior.

O termo Guarani, portanto, não corresponde a um único e grande povo indígena monolítico e fossilizado no tempo e no espaço. Os chamados subgrupos, parcialidades ou fragmentos, aí sim, correspondem a grupos étnicos específicos que se identificam e são identificados como Kaiowá, Mbyá ou Guarani (como no caso dos Ñandeva), por exemplo. Essa idéia parte da concepção barthiana de que o fenômeno da etnicidade e da identidade étnica é observável em situações de contato e definição de limites entre as culturas. Como perceber um fenômeno assim a partir de registros textuais incompletos (etnoistóricos) e evidências arqueológicas? Isto porque, dentre outras coisas, a prática discursiva, analisada por meio de procedimentos teóricometodológicos de natureza antropológica, constitui um desenvolvimento relativamente recente no campo das ciências sociais.

Desde fins do século XIX e meados do XX, muitas dessas diferenças étnicas emergiram $\mathrm{e}$ ainda seguem emergindo a partir da definição das fronteiras entre os Estados nacionais. $\mathrm{O}$ Brasil e o Paraguai são dois exemplos bastante conhecidos. Segundo Melià (2004), com a definição das fronteiras desses dois países, foram erguidos muros de Berlim dividindo territórios transnacionais dos Kaiowá, Mbyá e Ñandeva. Em tempos coloniais, por outro lado, muitos grupos de língua guarani se identificavam para os padres da Companhia de Jesus de acordo com o nome de sua principal liderança ou do lugar de ocupação tradicional, conforme registrado em trabalhos como o de Ítala Irene B. Becker (1992), Lideranças indígenas no começo das reduções jesuíticas da Província do Paraguay, uma das precursoras da etnoistória no Brasil.

Com efeito, o problema central está no fato de termos eleito um determinado tipo de tecnologia ceramista, associando-a a uma língua nativa, para construirmos elementos de identidade étnica a grupos que identificamos como Guarani, mas que, em sua maioria, não se identificavam e não se identificam dessa maneira. Ora, se a idéia de raça, língua ou cultura foi superada para a identificação de grupos étnicos, conforme proposto por Barth (1998 [1969]), por que teríamos de seguir atribuindo esta ou aquela identidade a partir de uma tradição tecnológica ceramista supostamente ligada a grupos de língua guarani? Este é um grande problema a ser pensado e repensado na arqueologia brasileira, para o qual não tenho aqui uma fórmula para sua definitiva solução. No entanto, parafraseando Nelson Rodrigues, citado por Viveiros de Castro (2002) na epígrafe do artigo "O nativo relativo", tenho a impressão de que o Guarani genérico, tal qual o imaginamos ou idealizamos na academia para a proposição de modelos interpretativos de longo alcance, nunca existiu de verdade.

Além de apresentar algumas considerações teórico-metodológicas pontuais, quero aqui entrar em uma discussão mais delicada, a qual, ultimamente, tem sido uma de minhas maiores preocupações no que se refere ao uso da arqueologia para a identificação de terras indígenas no Brasil, sobretudo no Mato Grosso do Sul.

Conforme é amplamente conhecido na historiografia e na literatura etnológica, nesse estado existem muitos conflitos fundiários entre comunidades indígenas e fazendeiros e, às vezes, até com colonos que foram assentados pelo governo central no antigo sul do Mato Grosso, atual Mato Grosso do Sul. ${ }^{5}$ Em conflitos desse tipo, a apreciação de direitos é feita pela justiça federal, e o que se tem observado são processos de desterritorialização de comunidades indígenas, os quais geralmente decorreram da expansão de frentes econômicas da sociedade nacional e seus desdobramentos posteriores. Essa situação foi gradativamente acirrada após o término da

\footnotetext{
5. A criação do Mato Grosso do Sul, a $22^{\mathrm{a}}$ unidade da federação, se deu por meio da Lei Complementar $n^{\circ} 31$, de 11/10/ 1977, promulgada na época do governo Ernesto Geisel, o penúltimo general a assumir a Presidência da República na época do regime militar (1964-1985). Esse novo estado surgiu do desmembramento da parte meridional do antigo Mato Grosso, uma área de $358.159 \mathrm{~km}^{2}$, e foi implantado a partir de $1 \% 1 / 1979$. Na historiografia regional, é comum o emprego do termo antigo sul de Mato Grosso para se referir à região compreendida pelo atual Mato Grosso do Sul antes da data de sua criação.
} 
guerra entre o Paraguai e a Tríplice Aliança (1864-1870), isto é, nas últimas décadas do século XIX e no decorrer do século XX. No entanto, a partir da década de 1980, sobretudo, os Kaiowá e os Guarani (Ñandeva) iniciaram um movimento étnico-social pela retomada de parte de seus antigos territórios, algo que parece estar longe de terminar (cf. Brand, 1997; Moreira da Silva, 2002; Pereira, 2003; Stefanes Pacheco, 2004).

Nesse contexto regional, desde a década de 1990 especialistas em arqueologia têm sido intimados pela justiça federal a elaborarem laudos periciais para averiguar se determinadas áreas em litígio são ou não de ocupação tradicional indígena, conforme determina a legislação brasileira. Por isso, durante a produção de uma perícia judicial, a busca pelo Guarani genérico, monolítico e fossilizado no tempo e no espaço, supostamente identificado por fragmentos cerâmicos da tradição Tupiguarani, associada a uma língua de mesmo nome, pode se converter em um problema de dimensões políticas preocu-

Figura 1: Mapa do estado do Mato Grosso do Sul com a indicação do município de Maracaju, onde está situada a terra indígena Sucuri’y.

\section{Mato Grosso do Sul}

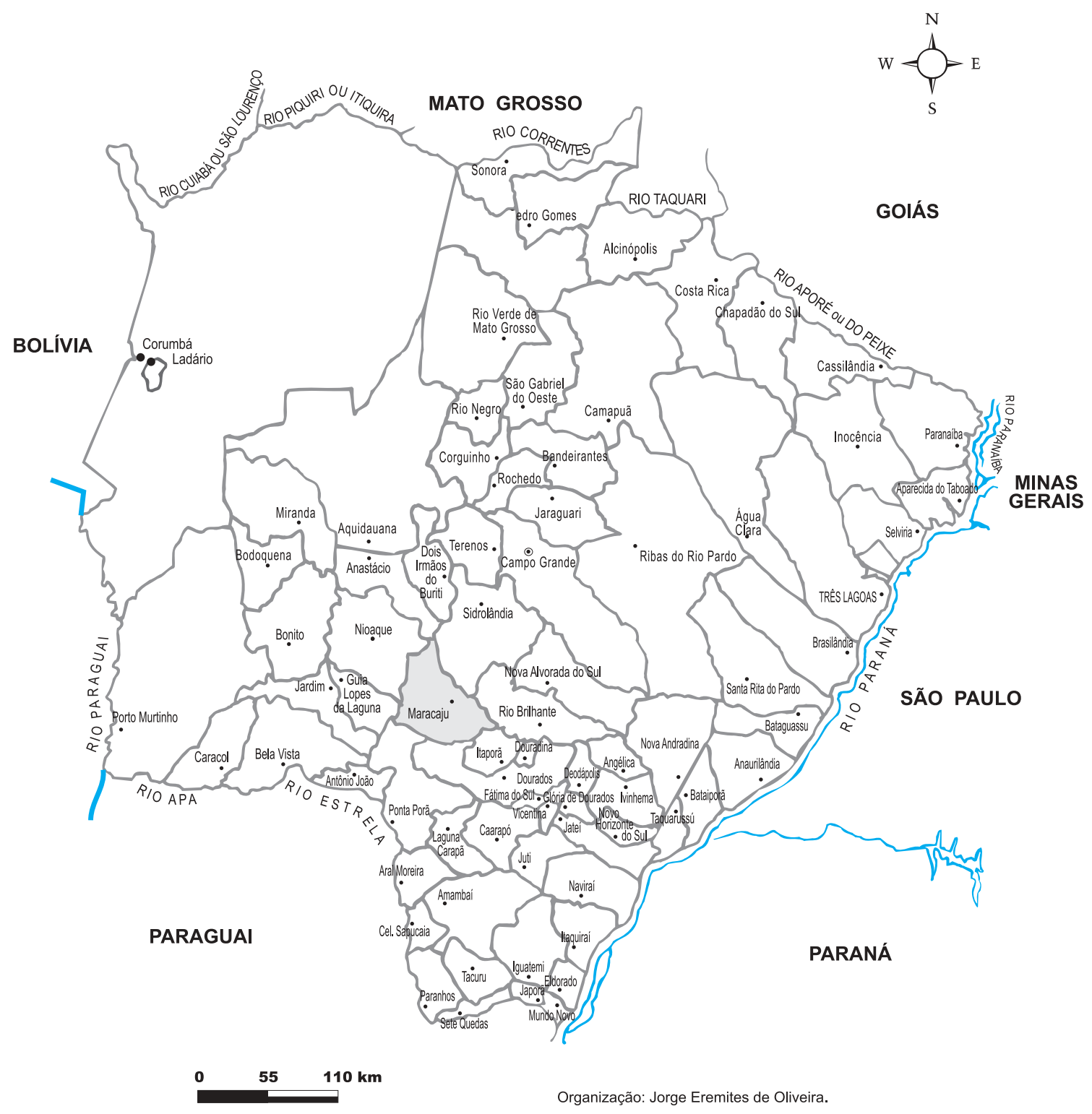


pantes. E este problema não foi, certamente, $o$ que motivou Brochado (1984) a redigir sua brilhante tese de doutorado.

Para ser mais específico, passarei a apresentar uma análise a respeito do laudo pericial sobre a terra indígena Sucuri'y, cujo relatório foi apresentado por um arqueólogo à $1^{\mathrm{a}}$ Vara da $1^{a}$ Seção Judiciária de Campo Grande, Mato Grosso do Sul, conforme consta nos autos do processo $n^{\circ}$ 97.0864-9. Essa terra indígena, cuja área reivindicada é de 535 hectares, faz parte do território de uma comunidade Kaiowá estabelecida no município de Maracaju, nas proxi-

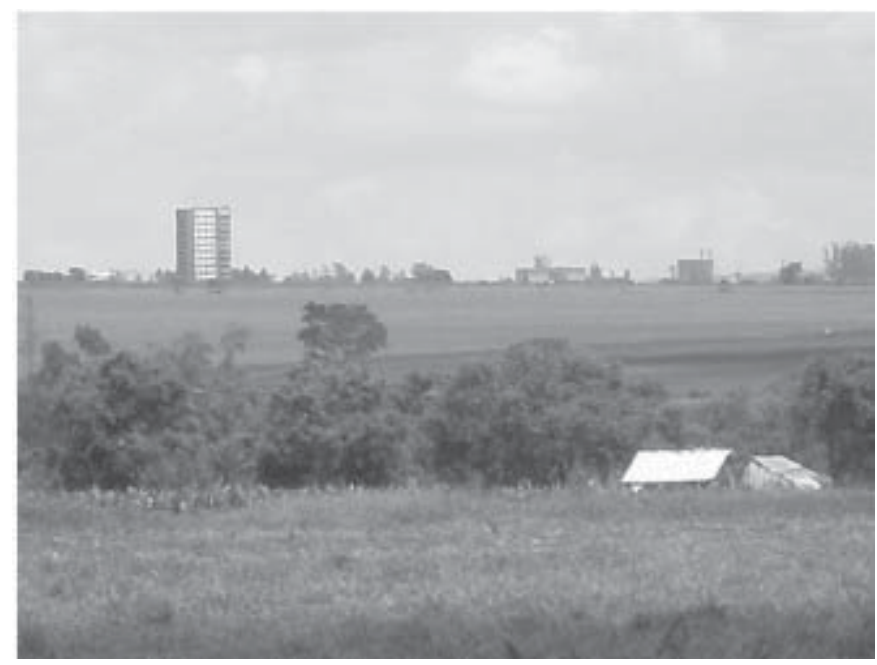

Figura 2: Vista panorâmica de parte da terra indígena Sucuri’y, tendo ao fundo a cidade de Maracaju. Foto: Jorge Eremites de Oliveira (nov./2006)

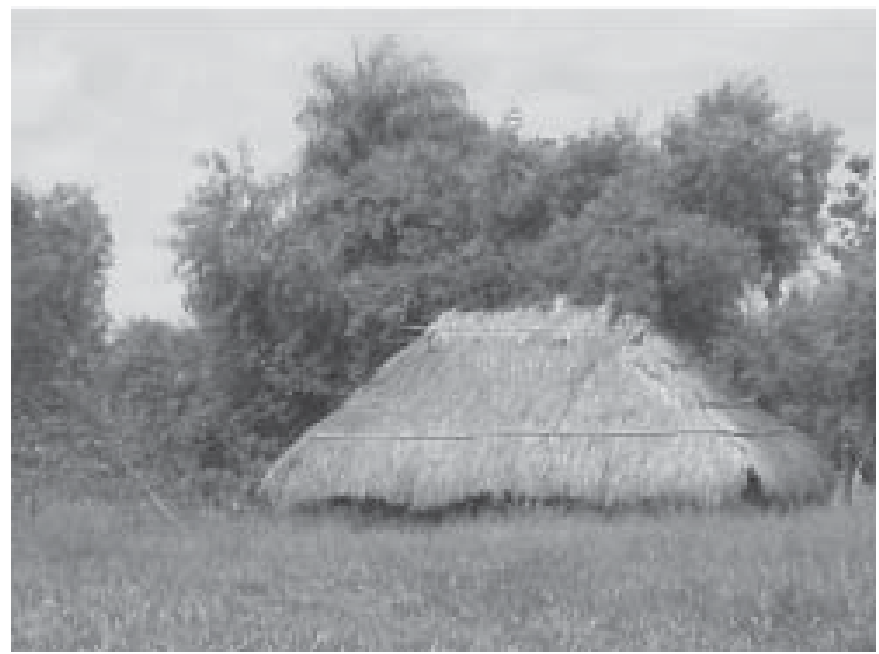

Figura 3: Habitação de uma família kaiowá na terra indígena Sucuri'y. Foto: Jorge Eremites de Oliveira (nov./2006) midades da serra de mesmo nome. Dessa área, apenas 65 hectares estão sendo atualmente ocupados por 167 indígenas, divididos em 39 famílias, segundo dados obtidos em fins de novembro de 2006, quanto estive naquela aldeia. $\mathrm{Na}$ área ocupada pelos Kaiowá funciona uma escola municipal localizada nas coordenadas UTM 695.104 E e 7.604.744 N, a uma altitude de $368 \mathrm{~m}$.

Ao analisar o laudo judicial em questão, cheguei à conclusão de que o perito do juízo direcionou grande parte de suas investigações para a história pré-colonial ("pré-história") da área em litígio. Isso fez com que ele concentrasse sua análise mais na imemorialidade e menos na tradicionalidade da ocupação indígena. Foi a essa estratégia impertinente que o perito mais recorreu durante os trabalhos de campo e isso ele próprio explicou na página 1.267 dos autos:

\begin{abstract}
A questão principal, que permanecia aberta, era se os dados arqueológicos coletados durante as diligências periciais estavam relacionados ao passado da Comunidade Indígena Kaiowá de Sucuri'y. Decidiu-se, em comum acordo, que seria necessário realizar novas escavações arqueológicas na área em litígio, isto com o objetivo de se tentar determinar se houve ou não essa vinculação temporal.
\end{abstract}

Seguindo procedimentos comuns na arqueologia pré-histórica, os quais remetem à idéia de imemorialidade, o perito chegou à seguinte conclusão, que consta nas páginas 1.278 e 1.279 dos autos:

A análise anterior nos permite pensar que a comunidade de Sucuriy é originária de um processo etno-histórico que desenvolveu-se na área do município de Maracaju, muito provavelmente precedente a este século e que, portanto tem, a mesma, direito a um espaço definido e suficiente para a preservação e reprodução de seu modo de ser étnico no contexto espacial que foi palco dos acontecimentos de seu passado.

Por outro lado, ao nosso ver, também não é justo que o problema do espaço vital necessário à revitalização cultural indígena seja solucionado através da desapropriação sumária de bens particulares (réus) que, com certeza, não 
são os responsáveis diretos, nem indiretos, pelos infortúnios que assolam os índios no passado e no presente na região. Os réus adquiriram as terras que atualmente ocupam produtivamente (que são parcialmente objeto da lide) de forma perfeitamente legal e em nenhum momento praticaram o esbulho de terras indígenas. Finalmente, ao nosso ver, a justiça só será restabelecida na questão quando os índios tiverem direito à [sic.] permanecer definitiva e pacificamente em um espaço necessário à sua sobrevivência, com qualidade de vida e de acordo com suas tradições, por eles aceito como tal. Como, por falta de provas inquestionáveis, as diligências periciais não conseguiram caracterizar a área em litígio como de posse permanente e ininterrupta por parte dos indígenas, cabe ao Governo Federal, por meio dos órgãos públicos habilitados para tal, solucionar o impasse, já que, constitucionalmente, a proteção e tutela das comunidades indígenas são de sua responsabilidade.

No tocante a esse aspecto, o mais plausível seria o arqueólogo ter concluído que, com base nos preceitos constitucionais, em especial o Artigo 231, $\S 1^{\circ}$, da Carta Constitucional de 1988, e nas provas por ele arroladas, a terra indígena Sucuri'y é ou não, de fato, uma área de ocupação tradicional indígena. A polêmica maior segue residindo na seguinte questão: o autor entendeu que seria necessário buscar "provas inquestionáveis" para caracterizar a área em litígio como sendo de "posse permanente e ininterrupta", por parte dos indígenas, desde tempos imemoriais até os dias de hoje. Esta é uma interpretação particular e equivocada que ele fez da lei, com a qual a assistente técnica do Ministério Público Federal, a antropóloga Elaine Amorim Carreira (2000), rebateu de maneira contundente e esclarecedora em seu parecer, conforme consta nas páginas $1.367 \mathrm{e}$ 1.368 do processo:

As noções de ocupação permanente e de terras tradicionalmente ocupadas não se referem ao império de um passado remoto e nem chegam a privilegiar as relações temporais, mas, sim, dizem respeito a maneiras típicas de envolvimento com o espaço, que podem ou não serem imemoriais e ininterruptas. A lógica histórica exige esse entendimento porque sabe- mos hoje da inexorável realidade dos acontecimentos ocorridos no passado, que reiteradamente seguiram uma política deliberada de expulsões e reduções das sociedades indígenas, deslocando-as continuamente de seus territórios tradicionais. Por isso, o permanente do texto constitucional refere-se a fatos concretos e efetivos da ocupação costumeira sobre determinada área, de modo mais ou menos estável e duradouro - em contraposição a estâncias temporárias e eventuais -, mas não requer indicar, e nem poderia dado o contrasenso histórico, exclusivamente os processos de ocupação continuada e seqüencial de terras indígenas. A lei não busca amparar direitos étnicos de povos abstratos, situados em algum lugar do passado. Busca sim amparar direitos de povos vivos e contemporâneos.

Não se limitando a titubear na hora de dizer se a área em litígio é ou não de ocupação tradicional indígena, o expert do juízo ainda apresentou seu ponto de vista particular acerca do que entende ser justo ou injusto para a resolução do litígio. Nesse aspecto, em específico, ele deu a entender que estava se colocando na posição do próprio magistrado, ou de um profundo conhecedor de direito constitucional e operador do direito, quando da apresentação de uma sentença. Por isso, o arqueólogo finalizou seu trabalho remetendo a solução do impasse à ação de órgãos governamentais. Paradoxalmente, a conclusão do arqueólogo contradiz as provas que ele mesmo arrolou nos autos, conforme explicado adiante. ${ }^{6}$

$\mathrm{O}$ perito afirmou, ainda, segundo consta na página 1.268 do processo, que ele deu início a escavações arqueológicas com o seguinte objetivo:

Iniciamos as escavações objetivando-se encontrar vestígios arqueológicos passíveis de

6. O referido arqueólogo compartilha a idéia de que "a questão da terra indígena é, pela legislação em vigor, um problema de âmbito federal, e é muito difícil achar culpados por erros cometidos no passado, ainda mais quando isso aconteceu havia muitas décadas", segundo consta em um artigo de sua autoria publicado nos Anais do VI Encontro de História de Mato Grosso do Sul (Campo Grande, UCDB, 2004, pp.1329.). Este ponto de vista é, em grande medida, inconsistente, haja vista que pode servir como um tipo de álibi para justificar certas análises equivocadas a respeito dos processos de esbulho e espoliação de terras tradicionalmente ocupadas por comunidades indígenas no Mato Grosso do Sul. 
datações laboratoriais, tais como carvões ou outros vestígios orgânicos e/ou fragmentos de cerâmica arqueológica, os quais permitiriam, inclusive, a identificação étnica de seus produtores [...]. (grifos meus)

A respeito das "datações laboratoriais", o arqueólogo certamente estava se referindo ao uso de dois métodos físico-químicos para a datação absoluta: (1) datação radiocarbônica, feita por meio da análise do carbono-14 $\left(\mathrm{C}^{14}\right)$, encontrado em restos orgânicos como ossos humanos e carvões de antigas fogueiras antrópicas; (2) datação por termoluminescência (TL), utilizada para a datação de cerâmica e material lítico, por exemplo. Ambos os métodos também são comuns em arqueologia pré-histórica e em outras subáreas da arqueologia, mas não constituem métodos tão precisos como a argüição do perito pode levar a pensar.

Em se tratando de datações pelo método radiocarbônico, sabe-se que este método "é demasiado impreciso para ser útil nos 400 anos do passado mais recente", conforme explicaram Collin Renfrew \& Paul Bahn (1998, p. 135), autores do Arqueología: teorías, métodos y práctica. Por outro lado, segundo os mesmos autores, o método de datação por termoluminescência, embora útil para datas dos últimos dez mil anos, ainda "é menos preciso que este na exatidão de suas datas" (Renfrew \& Bahn, 1998, p. 135).

Ora, se os dois métodos não são tão precisos assim e se datas antigas remetem mais à idéia de imemorialidade, pode-se deduzir, portanto, que esse procedimento metodológico não seria o mais recomendado para a realização dos trabalhos de perícia. Contudo, caso o perito tivesse encontrado fragmentos de cerâmica tipicamente Tupiguarani, conforme é amplamente conhecida na arqueologia sul-americana (ver La Salvia \& Brochado 1989), datada, por

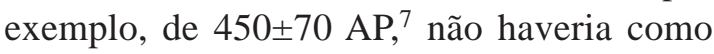
associá-la diretamente aos Kaiowá de Sucuri'y se ela não fizesse parte da memória social ou

7. AP significa anos "Antes do Presente", no qual o presente é, por convenção, o ano de 1950. Em inglês, essa sigla é BP (Before Present). No caso dessa data hipotética, o sinal " \pm " indica a margem de erro da datação, para mais ou para menos. possuísse sentido de tradicional para a comunidade indígena. ${ }^{8}$ Por este e outros motivos é que sigo argumentando que procedimentos metodológicos e linhas argumentativas comuns na arqueologia pré-histórica não são, pois, apropriados para esse tipo de trabalho.

Uma das questões que o expert deveria ter esclarecido diz respeito, por exemplo, ao início da ocupação da região pelas frentes de expansão econômica da sociedade nacional, algo que aconteceu entre fins do século XIX e as primeiras décadas do século XX. Por esse motivo, o fundamental da perícia seria esclarecer se, quando a cadeia dominial teve início, a terra era ou não ocupada pelos Kaiowá de Sucuri’y, em seu sentido mais amplo, pois os indígenas alegaram terem sido vítimas de processo de esbulho. ${ }^{9}$ Caso tenha ocorrido o espólio de suas

8. O "sentido de tradicional" a que me refiro está ligado àquilo que uma comunidade indígena dá significado de tradicional nos dias hoje, de acordo com seus usos, costumes e tradições, tal qual determina a Constituição Federal. Sobre o assunto, além dos trabalhos mencionados ao longo deste artigo, alguns outros são bastante elucidativos: (1) Carneiro da Cunha, M. (Org.). 1987. Os direitos do índio: ensaios $e$ documentos. São Paulo, Brasiliense; (2) Dallari, D. de A. 1994. Argumento antropológico e linguagem jurídica. In: Sampaio Silva, O. et al. (Org.). A perícia antropológica em processos judiciais. Florianópolis, Editora UFSC, p.103114; (3) Pacheco de Oliveira, J. 1994. Instrumentos de bordo: expectativas e possibilidades do trabalho do antropólogo em laudos periciais. In: Sampaio Silva, O. et al. (Org.). A perícia antropológica em processos judiciais. Florianópolis, Editora UFSC, p.115-139; (4) Souza Filho, C. F. M. de. 1998. O renascer dos povos indígenas para o direito. Curitiba, Juruá; (5) Afonso da Silva, J. 2001. Curso de direito constitucional positivo. 19. ed. São Paulo, Malheiros; (6) Barbosa, M. A. 2001. Autodeterminação: direito à diferença. Prefácio de Dalmo de Abreu Dallari. São Paulo, Plêiade/Fapesp; (7) Barbosa, M. A. 2001. Direito antropológico e terras indígenas no Brasil. São Paulo, Plêiade/Fapesp; (8) Pacheco de Oliveira, J. 2001. Os Caxixós do Capão do Zezinho: uma comunidade indígena distante de imagens da primitividade e do índio genérico. Relatório encaminhado à Funai. Rio de Janeiro, Museu Nacional/ UFRJ; (9) Monteiro, P. et al. 2004. Direitos indígenas no Brasil. Novos Estudos, São Paulo, 69:57-70; (10) Leite, I. B. (Org.). 2005. Laudos antropológicos em debate. Florianópolis, NUER/ABA; (11) Souza Lima, A. C. de \& Barreto Filho, H. T. (Org.). 2005. Antropologia e identificação: os antropólogos e a identificação de terras indígenas no Brasil, 1977-2002. Rio de Janeiro, Contra Capa Livra$\mathrm{ria} / \mathrm{Laced} / \mathrm{CNPq} /$ Faperj/IIEB.

9. Para analisar a cadeia dominial da área em litígio, faz-se necessário recorrer ao livro Os Corrêa, os Ponte, os Alves no planalto e serra de Maracajú: origem histórica, árvores genealógicas, do advogado e ex-delegado de polícia Altinor Barbosa Ferreira (1993). Essa obra de caráter memorialista e genealógica foi escrita com base em pesquisas cartoriais e informações orais registradas pelo próprio autor. 
terras, seria ainda necessário esclarecer como esse processo se deu, quais os indivíduos que o fizeram, como reagiu a comunidade de Sucuri'y e qual foi a ação do órgão indigenista oficial, a Fundação Nacional do Índio (Funai), no episódio.

Se o esbulho foi feito pelos primeiros ocupantes não-índios para conseguirem títulos imobiliários da área, então, salvo melhor entendimento, toda a cadeia dominial da área não tem validade à luz da legislação brasileira, independentemente da opinião do perito sobre o que ele entende ser ou não justo.

Além do que já foi explicado até o momento, há outras questões que precisam ser pontuadas neste trabalho.

Em primeiro lugar, conforme consta na página 1.267 dos autos, o perito afirmou que suas diligências foram feitas após "o estudo da bibliografia especializada, análise de fontes primárias e leitura dos autos". Em seu relatório consta a relação de 105 títulos, da página 1.285 à página 1.294 dos autos. Do total, ao menos 41 trabalhos, ou seja, 39,05\% do total da bibliografia arrolada, referem-se à arqueologia pré-histórica. ${ }^{10}$ Essa outra constatação também atesta, como dito antes, que o arqueólogo recorreu preferencialmente a procedimentos metodológicos e argumentos comuns nessa subárea da disciplina, não dando a devida importância para a literatura etnológica e etnoistórica referente aos Kaiowá. A estratégia dele de direcionar os trabalhos periciais mais para averiguar a imemorialidade da ocupação indígena na área em litígio constitui, nesse caso em particular, um vício observado ao longo de sua perícia.

Igualmente, no decorrer das respostas aos quesitos elaborados pelas partes, o perito sequer

\footnotetext{
10. A bibliografia arrolada no laudo pericial é praticamente a mesma que o autor relacionou em sua tese de doutorado, defendida em 1996 na USP, cujo tema central tem a ver com a pré-história de antigos grupos indígenas que se estabeleceram no planalto de Maracaju-Campo Grande, incluindo o município de Maracaju. Nesse trabalho, há um subitem de número 3.2, intitulado "Panorama etno-histórico da região de Maracaju", em que o perito fez um resumo da ocupação indígena no município homônimo, desde tempos imemoriais até momentos mais recentes, tratando inclusive do processo de esbulho a que os indígenas dizem ter sofrido na década de 1980. No entanto, esse não é um trabalho de sólida base etnográfica, até porque esta não foi a principal proposta do arqueólogo para a realização de sua pesquisa.
}

chegou a fazer referência a $10 \%$ das obras por ele relacionadas na bibliografia final de seu relatório. Nas páginas 1.265 e 1.269 , por exemplo, há referência a um trabalho de sua autoria que não foi encontrado na relação bibliográfica da página 1.289 dos autos. Provavelmente o autor se referiu a sua tese de doutorado, em específico à parte em que ele analisou a tecnologia lítica de grupos pré-coloniais que ocuparam a Serra de Maracaju em tempos imemoriais, assunto que em nada contribui para a elucidação dos acontecimentos.

Outras obras importantes, aí sim relevantes para o esclarecimento dos fatos, não foram arroladas e discutidas no laudo pericial. Este é o caso da tese de doutorado de Antonio Brand (1997), denominada $O$ impacto da perda da terra sobre a tradição kaiowá/guarani: os difíceis caminhos da palavra. A referida monografia é um trabalho de fôlego que contém a relação de vários documentos e um mapa das áreas de ocupação tradicional kaiowá e ñandeva no estado e, por isso, definitivamente não poderia ter sido ignorada. Há ainda clássicos que igualmente não foram discutidos, a exemplo de Aspectos fundamentais da cultura Guarani, de Egon Schaden (1974), dentre muitas outras obras que o profissional tinha ciência na época, conforme um livro de sua própria autoria, cuja primeira edição é de 1992. Esta constatação também foi feita de maneira semelhante pela assistente técnica do Ministério Público Federal em seu parecer, de acordo com o que consta nos autos.

Fontes desse tipo deveriam ter sido analisadas e discutidas para responder, por exemplo, ao primeiro quesito apresentado pelo juízo: "1. Estabeleça o Senhor Perito o local e o período em que os índios Guarani-Kaiowá habitavamocuparam (no sentido amplo de caçar, pescar e coletar) a área mencionada na petição inicial, se isso ocorreu". Como não o foram, as respostas também não são consistentes do ponto de vista histórico e antropológico.

Em segundo lugar, o levantamento arqueológico foi concluído com base em informações orais obtidas de membros da comunidade indígena. Isso é o que geralmente se chama de levantamento oportunístico de sítios arqueoló- 
gicos. ${ }^{11}$ Trata-se de um procedimento pertinente para trabalhos dessa natureza, desde que direcionado para averiguar a tradicionalidade da ocupação indígena e caso o pesquisador tenha entendido o idioma cultural do grupo.

Diversos pontos arrolados durante a perícia (antigas residências, lugares de valor mágicoreligioso, aterros sob forma de montículos, prováveis sepulturas humanas, trilhas, áreas de caça etc.), associados à toponímia em língua Guarani conhecida para a região, à memória coletiva da comunidade e a fontes textuais mencionadas no processo, chamam a atenção para a tese de que os Kaiowá estão ocupando aquela área de acordo com seus usos, costumes e tradições. Essas provas vão ao encontro da noção de oguata, palavra que em guarani se refere a um modus vivendi caracterizado por grande mobilidade espacial, no sentido de andar, caminhar, circular, viajar e transitar, conforme é amplamente conhecido na literatura etnológica e etnoistórica. A noção de oguata não deve ser vista como algum tipo de nomadismo ou perambulação errante, sem direção certa e ausente de estratégias de territorialidade. Pelo contrário, tem a ver com mobilidade espacial em uma área reconhecida como território tradicional para os próprios Kaiowá.

Registra-se, contudo, e mais uma vez, que não é a ocorrência de evidências arqueológicas imemoriais, como artefatos líticos e cerâmicos, que poderiam ou não comprovar a tradicionalidade da ocupação indígena na área periciada. A comprovação deveria ter sido feita, também, por meio da análise minuciosa de outras evidências materiais, tais como: "latas velhas", "sola de sapato", "entulho de lixo", locais de importância simbólica para atividades de caça (como o registrado como ogatawa), "alto topográfico" onde teria existido uma oga pysy etc. ${ }^{12}$ Todas essas evidências foram arroladas pelo expert

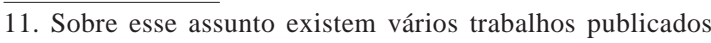
no país, como o estudo pioneiro realizado pelo arqueólogo Walter A. Neves (1984) no estado de São Paulo, denominado A evolução do levantamento arqueológico na bacia do Alto Guapeí, SP.

12. Oga pysy é uma unidade residencial tipicamente kaiowá, feita de madeira e coberta com capim sapé, onde geralmente residia uma família extensa, denominada te'yi. Há também construções com esta mesma denominação que eram e ainda são destinadas a rituais religiosos, às vezes até com
}

da justiça federal nas páginas 1.262 e 1.263 dos autos, mas sobre elas não foi apresentada qualquer análise etnográfica ou arqueológica à altura do que se faz na antropologia ou na subárea da arqueologia histórica, respectivamente. ${ }^{13}$ Tampouco sobre o material arqueológico imemorial recolhido in loco, como os artefatos líticos, foi apresentada uma análise meticulosa, o que atesta ainda mais a fragilidade da perícia. Por vezes, foram feitas ainda referências a suposições do tipo "aparentemente" e "provavelmente", as quais, associadas ao descrédito dado à memória e à tradição oral dos Kaiowá, assim como à literatura etnológica e etnoistórica, contribuíram para corroborar a conclusão final do perito, reproduzida anteriormente.

Em terceiro lugar, as entrevistas com alguns indígenas, transcritas e anexadas nos autos, também sustentam a tese da ocupação tradicional kaiowá da terra indígena Sucuri'y. Elas ainda apontam para o processo de esbulho que os índios afirmam ter sofrido. Sem embargo a essa proposição, entendo que, à luz da história oral e da etnografia, teria sido de bom alvitre se o perito tivesse tido alguns momentos a sós com a comunidade indígena. ${ }^{14}$ Dessa forma, ele poderia ter realizado entrevistas e observações etnográficas com vistas a recolher maiores subsídios para a elaboração do laudo. Em outros

outras configurações arquitetônicas. O perito grafou esta palavra de maneira equivocada (oga pysi), pois em guarani o "y" não tem o mesmo som que o "i". Ogatawa, por sua vez, se é que o perito registrou corretamente esta outra palavra, refere-se a um "povoado" ou ainda a um lugar de valor simbólico. Em guarani a palavra "oga" significa casa, local, moradia, e "táva" ou "tawa" diz respeito a povo, aldeia, povoação, localidade (cf. Krivoshein de Canese \& Acosta Alcaraz, 1997).

13. A arqueologia histórica pode ser entendida "como o estudo arqueológico dos aspectos materiais em termos históricos, culturais e sociais concretos, dos efeitos do mercantilismo e do capitalismo que foi trazido da Europa em fins do século XV e que continua em ação ainda hoje" (Orser Jr., 1992, p. 23) [itálico no original].

14. Na opinião de Verena Alberti (1990:1-2): "Se podemos arriscar uma rápida definição, diríamos que a história oral é um método de pesquisa (histórica, antropológica, sociológica etc.) que privilegia a realização de entrevistas com pessoas que participaram de, ou testemunharam, acontecimentos, conjunturas, visões de mundo, como forma de se aproximar do objeto de estudo. Como conseqüência, o método da história oral produz fontes de consulta (as entrevistas) para outros estudos, podendo ser reunidas em um acervo aberto a pesquisadores. Trata-se de estudar aconteci 
momentos, os assistentes técnicos das partes também poderiam fazer as entrevistas e observações etnográficas com os mesmos indivíduos, igualmente a sós, juntando elementos para a elaboração de seus estudos.

Desconheço a prerrogativa de o perito ter de fazer um laudo judicial em consenso com os assistentes técnicos, haja vista o conflito de interesses, ou ainda de ele estar legalmente obrigado a realizar ou participar de entrevistas coletivas, não podendo contar com momentos a sós para as partes envolvidas no processo. Entrevistas coletivas, aliás, quando feitas por vários entrevistadores ao mesmo tempo (perito, assistentes técnicos e outros), podem criar um ambiente tenso e induzir a análise dos entrevistados para a obtenção de respostas que convêm a uma das partes. Este é um dos motivos pelos quais elas devem ser evitadas, sob pena de se cair em subjetivismo profissional que pode macular a imparcialidade do laudo pericial.

Mais ainda, o processo de ocupação tradicional e o esbulho a que os Kaiowá se referem fazem parte da memória social de toda uma comunidade e não de um único indivíduo. Essa memória recua há mais de cem anos, conforme consta na página 1.266 dos autos, e, por ser coletiva e pautada por uma conduta articulada, deveria ter sido analisada com maior refino e profundidade. ${ }^{15}$

Em quarto lugar, está transparente que as pesquisas arqueológicas realizadas na área em litígio causaram constrangimento aos indígenas, pois alguns deles alegaram "ter havido violação

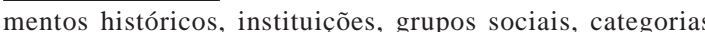
profissionais, movimentos, etc., à luz de depoimentos de pessoas que deles participaram ou os testemunharam". Entretanto, quando no contexto de perícias judiciais do tipo da que aqui está sendo analisada, esses depoimentos orais não devem ser confundidos com depoimentos tomados em juízo, tampouco o método da história oral pode ser considerado como um procedimento metodológico mais preciso ou que se sobrepõe em relação ao método etnográfico.

15. Entre povos indígenas sul-americanos, antropólogos geralmente não conseguem fazer diagramas de parentesco indicando mais de cinco gerações das quais descende um indivíduo de referência, denominado ego ("eu" em latim). Não é de se estranhar, então, que a memória coletiva dos Kaiowá possa recuar em torno de uns 150 anos, haja vista que uma geração tem em média de 20 a 25 anos. O que vai além dessa cronologia está no campo do imemorial e sua interpretação exige muita habilidade etnográfica e etnológica. de sepulturas", quer dizer, a profanação de túmulos, de acordo com o que foi registrado pelo próprio perito na página 1.267 dos autos. Significa dizer que lugares sagrados não deveriam ter sido perturbados por meio de escavações arqueológicas, pois constituem locais que, independentemente de terem ou não esqueletos humanos, são de grande significado para os Kaiowá. ${ }^{16}$

Esse tipo de procedimento contraria certas orientações comuns nas ciências sociais, conforme se pode atestar através de uma leitura do artigo "Restos humanos e arqueologia histórica: uma questão de ética", de Tania Andrade Lima (1994) ${ }^{17}$ Entretanto, se o perito tivesse encontrado restos humanos memoriais, será que haveria como datá-los tão precisamente pelo método radiocarbônico, como explicado anteriormente? Mas, em supondo ainda que pudesse vir a datálos com $100 \%$ de precisão, o passo seguinte teria de ser a realização de exames comparativos entre o DNA dos ossos humanos resgatados e o DNA de todos os membros da comunidade de Sucuri'y? Seria realmente necessário tudo isso para dar crédito à memória social coletiva de uma comunidade indígena, às evidências materiais encontradas in loco e às fontes textuais conhecidas? Em minha opinião, definitivamente não. Este é um típico exemplo de inabilidade etnográfica, apoiada em uma materialidade radical, algo que não se deve fazer para compreender o idioma cultural de um grupo étnico.

Daí a pertinência da análise apresentada por Rosely Aparecida Stefanes Pacheco, cujo

\footnotetext{
16. A prática arqueológica não se dá apenas por meio de escavações arqueológicas. Evidências materiais encontradas na superfície dos terrenos também podem ser analisadas com bastante sucesso, conforme comprovado em vários estudos publicados no Brasil (ver Caldarelli, 1997; Caldarelli, 1999; Eremites de Oliveira, 2002).

17. Durante o XIII Congresso da Sociedade de Arqueologia Brasileira, um grupo de antropólogos e arqueólogos brasileiros, preocupado com questões dessa natureza, propôs, durante a assembléia da $\mathrm{SAB}$, a apreciação de um documento sobre o assunto. O documento, que foi aprovado pelos presentes com apenas um voto em contrário, solicita do Instituto do Patrimônio Histórico e Artístico Nacional (Iphan) que não autorize projetos de pesquisa que impliquem a escavação de sepultamentos humanos em terras indígenas e em terras de descendentes de negros escravizados, sem que o responsável pelos estudos tenha a expressa e prévia autorização formal por parte das comunidades interessadas.
} 
estudo realizado é de grande relevância para a compreensão dos conflitos fundiários entre índios e fazendeiros no estado. Segue o que ela escreveu sobre o tema:

Diante do exposto, no antigo sul de Mato Grosso, como em outras áreas do país, no que concerne aos direitos indígenas às suas terras, sempre se vislumbrou o modelo de ação que fortemente privilegia o campo jurídico, visando, nesse sentido, encontrar registros que atestem a antiguidade da ocupação. Segundo esta lógica, a ausência de meios documentais de comprovação de um vínculo pretérito entre os remanescentes indígenas e as terras reivindicadas inviabilizaria qualquer tentativa de recuperá-las. Entre aqueles signatários desta idéia, sua atenção para a solução dos litígios fundiários regularmente está centrada na Escrita do Estado, como se somente esta fosse a forma mais importante de constituição de direitos, em detrimento de outras evidências de ocupação. (Stefanes Pacheco, 2004, p. 41)

Sabendo que os Kaiowá constituem um grupo étnico de tradição oral, não haveria o porquê de desprezar duas categorias de provas: (1) a memória social da comunidade; (2) as evidências materiais memoriais que atestam sua presença na área em litígio. Proceder de modo contrário sugere o comprometimento da própria imparcialidade do laudo pericial e/ou atesta a inabilidade do profissional nomeado pelo juízo.

Além do mais, os Kaiowá comumente não têm "cemitérios" iguais aos da sociedade nacional: recintos bem delimitados para guardar os mortos, consistindo em áreas mantidas limpas e visitadas em datas especiais; sepulturas com símbolos cristãos, principalmente cruzes; mortos enterrados em urnas funerárias de madeira, em posição de decúbito dorsal etc. Quando o são dessa forma é porque houve influências de administradores do órgão indigenista oficial e/ ou de missionários religiosos (católicos e/ou evangélicos). Esta constatação é largamente conhecida na literatura etnológica e etnoistória, desde tempos coloniais, conforme pude constatar in loco junto à comunidade Kaiowá de Panambizinho (Eremites de Oliveira \& Pastore, 2002), em Dourados, no ano de 2001, e mais recentemente, em 2005, junto à de Taquara, em Juti, ambas no Mato Grosso do Sul.
Para os Kaiowá, o lugar onde os mortos foram sepultados, sobremaneira em se tratando de indivíduos com prestígio social, como caciques e rezadores, não é um espaço venerado pelo grupo. É um lugar que deve permanecer no passado e quase que apagado da memória dos vivos. Muitas vezes os locais de enterramento correspondem a antigas residências onde as pessoas viveram, as quais logo após a partida do morto foram abandonadas e destruídas com fogo. Acompanhando os mortos, geralmente são enterrados ou deixados ao lado das sepulturas vários de seus pertences. Hoje em dia esses pertences podem ser desde um colar de contas até uma bicicleta. Eles acreditam na dualidade da alma, quer dizer, que as pessoas têm duas almas, uma carnal (anguery) e outra espiritual (ñe'e). A alma carnal permanece com o defunto e não deve ser lembrada, pois traz más influências à saúde e à convivência social dos membros da comunidade. Portanto, locais sagrados onde estão os mortos não deveriam e não devem ser profanados por escavação alguma, sob pena de perturbar a ordem social e espiritual dos indígenas. ${ }^{18}$

Acrescenta-se ainda que a área em litígio sofreu muitos impactos ambientais negativos, a exemplo de desmatamentos, queimadas e formação de pastagens para bovinos, motivo de rápidas transformações na paisagem local. Impactos assim causaram, indubitavelmente, a destruição de evidências materiais sobre a presença indígena em Sucuri'y, sejam imemoriais, sejam tradicionais. Este assunto também não foi aprofundado no laudo, mas deveria fazer parte de uma avaliação arqueológica geral da área periciada.

Em quinto lugar, ainda que o perito tenha avaliado que as informações orais dos índios foram contraditas por não-índios, o que não é raro quando entrevistas são feitas em um contexto de disputa judicial, está cristalino que parte dos depoimentos dos Kaiowá vai ao

\footnotetext{
18. Há muitíssimas fontes escritas sobre a religiosidade dos grupos étnicos de língua guarani. A produção mais relevante teve início com os padres da Companhia de Jesus, no século XVII, conforme se pode comprovar por meio de uma análise apurada de obras analisadas por Melià et al. (1976, 1987), Chamorro (1995, 1998), Pereira (1999, 2004) e Mura (2004)
} 
encontro de certas fontes textuais. Exemplo disso está na clareza com que o esbulho de indígenas está presente na memória de descendentes dos primeiros não-índios que fundaram o município de Maracaju. Isso tanto é verdade que na página 1.277 dos autos o arqueólogo fez menção a um trecho do livro Maracaju e sua gente, de Francisco Bernardes Ferreira \& Albino Pereira da Rosa, ${ }^{19}$ publicado localmente em 1988. A década da publicação do livro coincide com a década em que os Kaiowá afirmaram que foram expulsos da área. Nesse livro consta ipsis litteris o seguinte:

Durante os primeiros anos de adaptação da família Alves de Lima na região do Planalto da Serra de Maracaju, nem sempre as coisas correram em paz. Havia muitas aldeias indígenas, espalhadas desde as cabeceiras dos rios Santa Maria e Brilhante, até as margens do Paraná. Os índios constituíam uma ameaça permanente para os fazendeiros que, por diversas vezes, tiveram de empregar de muita astúcia, e até mesmo o uso de armas de fogo para rechaçar os seus ataques traiçoeiros e perigosos. Com o decorrer do tempo, depois de muita luta e até de combates sanguinolentos, teve lugar uma aproximação pacífica dos grupos em litígio, permitindo o estabelecimento de um clima de paz e maior tranqüilidade. (Ferreira \& Rosa, 1988,p. 111)

A transcrição acima apresentada foi escrita por Francisco Bernardes Ferreira, responsável pela redação da segunda parte da obra citada (da página 73 a 167). Faz parte de um livro produzido por dois renomados memorialistas da região, pessoas conhecedoras do direito e autores de um livro sobre a história de Maracaju. Nessa passagem, também citada na página 93 da tese de doutorado do perito, estão claros alguns

19. Albino Pereira da Rosa nasceu em Maracaju, no dia 13 de junho de 1914, graduou-se em direito pela antiga Universidade do Brasil, no Rio de Janeiro, foi auxiliar de ministro na Procuradoria Geral, procurador de autarquia da Previdência Social e autor de livros jurídicos. Francisco Bernardes Ferreira nasceu em Uberaba, Minas Gerais, no dia 21 de janeiro de 1903, trabalhou em Maracaju como proprietário da Farmácia Popular e também em fazendas de gado da região, chegando a exercer as funções públicas de juiz de paz, vereador, promotor interino da justiça e prefeito daquele município. Portanto, os autores do livro Maracaju e sua gente foram pessoas cultas, por assim dizer, que vivenciaram o processo histórico regional no século XX. pontos cruciais para o conhecimento de direitos: (1) que muitas aldeias indígenas estavam estabelecidas na região quando ali chegaram os primeiros não-índios fundadores do município, entre fins do século XIX e primeiras décadas do XX, quer dizer, em tempos memoriais; ${ }^{20}(2)$ que os contatos iniciais entre os índios e esses fundadores não foram pacíficos, tendo havido até o emprego de armas de fogo para rechaçar os primeiros ocupantes nativos da região, os quais foram vistos como "uma ameaça permanente"; (3) depois desses conflitos supostamente houve "o estabelecimento de um clima de paz e maior tranquiilidade", o que teria ocorrido quando se consolidou o processo de esbulho dos índios de grande parte da área por eles ocupada de maneira tradicional.

É isso o que resumidamente diz um estudo sobre a história de Maracaju, escrita por homens importantes da política local, e é isso o que em linhas gerais os Kaiowá explicaram para o perito e para os assistentes técnicos. Ambas as versões não são contraditórias, pelo contrário, são confluentes e fazem parte de uma mesma história presente na memória coletiva de índios e nãoíndios. $^{21}$

Essa ainda é a mesma realidade sóciohistórica de muitas outras regiões do antigo sul do Mato Grosso, hoje Mato Grosso do Sul, onde atualmente há conflitos fundiários envolvendo índios e fazendeiros. A questão central reside na origem da estrutura fundiária estadual. Ela está no fato de o antigo estado do Mato Grosso ter se apoderado de territórios indígenas, o que se deu com a promulgação da Constituição Federal de 1891, declarando-os como terras devolutas para depois serem repassadas a terceiros. Muitos desses terceiros primeiramente

\footnotetext{
20. Segundo o referido expert: "Em 8 de junho de 1924, o Governo do Estado de Mato Grosso elevou o pequeno aglomerado à categoria de Distrito da Paz, sob a jurisdição da Comarca de Nioaque. No ano de 1928, quando a população urbana girava em torno de mil pessoas e a rural, em dez mil, a região desmembrou-se de Nioaque e o distrito foi promovido a [sic.] sede do município de Maracaju”. Esta informação consta na p. 106 da tese de doutorado do perito da justiça federal.

21. Além dos Kaiowá, os Ofayé-Xavante, cujos descendentes vivem hoje em Brasilândia, também tiveram suas terras espoliadas na região de Maracaju e adjacências, conforme consta no livro de Carlos Alberto dos Santos Dutra, a obra Ofaié: morte e vida de um povo (Dutra, 1996).
} 
promoveram a expulsão dos nativos de seus territórios e, posteriormente, obtiveram, por parte dos órgãos estaduais de controle fundiário, as devidas certidões imobiliárias para a legalização de suas propriedades.

Ao analisar situações desse tipo, a partir do estudo de vários processos judiciais no estado, Moreira da Silva assim resumiu a situação:

No Mato Grosso do Sul, notadamente no território kaiowá e ñandeva, o processo de espoliação de terras indígenas pelas frentes de expansão econômica, com apoio oficial, realizou-se à revelia de todo o ordenamento jurídico de proteção aos direitos indígenas vigentes, inclusive o Alvará de 1680 que nunca foi revogado. (Moreira da Silva, 2002, p. 149)

Stefanes Pacheco, por sua vez, igualmente analisando vários processos judiciais, fez duas interessantes avaliações sobre $\mathrm{o}$ assunto.

A primeira:

É certo que os indígenas foram atropelados pela ação estatal, sendo este o principal responsável por grande parte dos infortúnios que assolam estas sociedades; porém, o Estado não agiu sozinho, estava amparado por uma classe ávida de benesses e que via nestas terras uma forma de resolver seus anseios. (Stefanes Pacheco, 2004, p. 36)

A segunda:

O resultado é uma trama de títulos que vêm tentando obstaculizar o questionamento jurídico por parte dos indígenas no tocante a seus direitos de acesso a terra. (Stefanes Pacheco, 2004, p. 41)

A seguir, passo a registrar o que próprio perito do juízo escreveu em um subitem de sua tese de doutorado, elaborado sem a realização de observação participante (pesquisa etnográfica), porém centrado em uma análise histórica com base em fontes textuais produzidas por nãoíndios. ${ }^{22}$

22. As quatro citações apresentadas a seguir foram copiadas da tese de doutorado do perito: primeira (p.93), segunda (p. 94), terceira (p.106) e quarta (p.107-108).
Primeira:

Na década de oitenta do século XIX, a região do planalto maracajuano assistiu, concomitantemente à expansão da atividade ervateira, à chegada de novas levas de colonos, principalmente família oriundas do sul de Minas Gerais. Diversas fazendas de gado foram constituídas na área do atual município de Maracaju e os colonos passaram a disputar, com os indígenas, a posse das vastas planuras maracajuanas. A resistência indígena à invasão de seu território ancestral não foi pacífica, isto podemos observar, por exemplo, na descrição feita por um historiador municipal [sic.] a seguir produzida: [...].

A citação que o arqueólogo apresentou é a mesma reproduzida anteriormente, transcrita da página 111 do livro Maracaju e sua gente (Ferreira \& Rosa, 1988), e por isso dispensa uma outra menção.

A segunda:

A família Alves de Lima foi uma das dezenas que se instalaram no planalto nessa época. Porém, entre todas, esta merece destaque no âmbito deste trabalho, pois foram os membros dessa família os que se instalaram pioneiramente na área compreendida entre o córrego Cachoeira e o rio Santa Maria, onde esta [sic.] localizado o sítio "Maracaju-1", fundando aí a fazenda Pulador, na confluência do córrego Pulador com o Cachoeira. Esta fazenda existe ainda nos dias de hoje [...].

\section{Terceira:}

Muito provavelmente, nas primeiras décadas deste século [século $X X$ ], a região que estamos enfocando ainda abrigava, talvez, algumas centenas de índios kaiowás dispersos entre os bosques remanescentes da cobertura original ou vivendo agregados nas recém-instaladas fazendas como mão-de-obra desqualificada, conservando ainda parte de seus costumes e uma obstinação em preservar o seu modo de ser, isto no território onde mantêm relações simbólicas com seu passado e antepassados. A partir da década de 1940, o panorama ambiental e sócio-econômico passou por aceleradas mudanças. Nos primeiros anos dessa década o tronco ferroviário da 'Noroeste do Brasil', ligando Ponta Porá a Campo Grande, estava 
concluído. A facilidade de acesso e a de circulação de mercadorias daí advindas viabilizou, pelos anos seguintes, o crescimento das atividades agropastoris e o processo de urbanização do município. O espaço vital para os índios reduziu-se proporcionalmente ao ritmo do desenvolvimento econômico.

A quarta foi escrita após o autor fazer referência ao estudo de identificação que Santos (1986) elaborou e que foi apresentado à Funai:

Em 1983, algumas famílias indígenas que viviam agregadas em fazendas da região retornaram à área pretendida como território imemorial, nas proximidades da Fazenda Sete Voltas. Outras famílias se reagruparam, em 1984, em um lote nas margens da rodovia Rio Brilhante-Maracaju, e mais algumas na periferia da cidade de Maracaju. Diversos atritos ocorreram entre os índios e alguns fazendeiros, estes apoiados por algumas autoridades municipais. As tensões aumentaram e, no meio do ano de 1986, uma ação conjunta, realizada pela Prefeitura Municipal, pela Polícia Militar do Estado e pelo Terrasul, com apoio de alguns fazendeiros, desalojou os índios do município, enviando-os para o Posto Indígena de Dourados.

A convivência com grupos étnicos distintos e o congestionamento demográfico do PI de Dourados desgastou as relações dos recémchegados com os habitantes tradicionais do lugar. A desarmonia e os graves problemas sócio-culturais de PI de Dourados os forçou, novamente, a procurar um local onde pudessem realizar o assentamento tribal.

Atualmente, a auto-denominada comunidade Sucuri [sic.] [...], enquanto aguarda um desfecho para o processo demarcatório de suas terras, está instalada em uma área urbana de 5 hectares, cedida a título de comodato pela Prefeitura de Rio Brilhante, no distrito de Prudêncio Thomaz (Aroeira), e resiste sobrevivendo da venda de artesanato nas margens da rodovia BR-163.

As citações apresentadas são relevantes para a compreensão da história dos contatos entre os Kaiowá e a sociedade nacional e para o esclarecimento dos fatos. Nas passagens, o autor registrou o termo "território imemorial" para se referir à área reivindicada pelos Kaiowá e apresentou um sucinto panorama acerca dos processos de desterritorialização e reterrito- rialização enfrentados pela própria comunidade de Sucuri'y. A análise que ele fez em um capítulo específico de sua tese de doutorado vai ao encontro daquilo que em linhas gerais os Kaiowá lhe disseram anos depois, quando o arqueólogo, na condição de perito do juízo, esteve com os índios para a realização do laudo judicial em análise.

A constatação apresentada reforça ainda mais a tese da tradicionalidade da ocupação indígena em Sucuri'y e a do esbulho a que os Kaiowá alegam ter sofrido. Também corrobora a avaliação de que o perito cometeu vícios ao buscar provas imemoriais sobre a posse permanente e ininterrupta, desde tempos imemoriais até os dias de hoje, a respeito da presença kaiowá na área em litígio. No caso em tela, o perito não esclareceu as razões da suposta mudança de seu posicionamento quanto ao direito de posse dos Kaiowá em relação às terras que reivindicam em Maracaju, e o porquê, especificamente, de a comunidade indígena não ter vínculos históricos e culturais (tradicionais) com a área periciada, contrariando a análise aqui apresentada.

Mais recentemente, em 2006, a justiça federal no Mato Grosso do Sul acatou um pedido do Ministério Público Federal sobre a necessidade da realização de nova perícia em Sucuri'y, desta vez não mais arqueológica e sim antropológica. Em seguida, o juízo nomeou um etnólogo para a realização dos novos estudos, cujos resultados indicaram que aquela área em litígio é terra tradicionalmente ocupada pelos Kaiowá.

Conclui-se, portanto, que a relação entre identidade étnica e evidências arqueológicas é um tema que ainda precisa ser debatido com mais profundidade na arqueologia brasileira. Trata-se de um assunto polêmico e, até certo ponto, delicado sob vários aspectos. Não obstante essa realidade, defendo a tese de que o uso de analogias históricas ou etnográficas diretas é algo inapropriado para a atribuição desta ou daquela identidade étnica a evidências arqueológicas de um passado pré-colonial. Por este motivo principal é que se faz necessário superar um antigo paradigma histórico-cultural, qual seja, a de que a etnicidade ou a identidade étnica deve ser tratada como um fenômeno estático, fossi- 
lizado no tempo e no espaço e que surge de fora para dentro dos grupos étnicos. Pelo contrário, é um fenômeno dinâmico que emerge do interior dos grupos étnicos para a exterioridade, em situações de contatos interculturais.

Ademais, o que pode parecer apenas um procedimento teórico-metodológico impertinente e inadequado, restrito ao debate acadêmico, pode se converter em problemas políticos de grandes proporções em que direitos de grupos étnicos podem estar sendo objeto de avaliação na esfera judicial. Daí a necessidade iminente de a arqueologia brasileira aprofundar o diálogo com outros campos do conhecimento, sobretudo com a antropologia, mas não se esquecendo da história e até mesmo do direito, incorporando novos aportes teórico-metodológicos e superando certas defasagens que tem em relação à arqueologia mundial.

\section{Agradecimentos}

Quero aqui agradecer a todos os amigos e amigas com os quais mantive interlocução durante os estudos que culminaram com a elaboração deste artigo, em especial aos colegas do Laboratório de Arqueologia, Etnologia e História Indígena da UFGD, que gentilmente leram as primeiras versões do trabalho e apresentaram críticas e sugestões de grande relevância para sua finalização. São eles: Graciela Chamorro, Levi Marques Pereira e Protásio Paulo Langer. As idéias aqui apresentadas, contudo, são de minha inteira responsabilidade. Meus agradecimentos também são de igual proporção à amiga Tania Andrade Lima, com quem tenho compartilhado muitas de minhas preocupações sobre os rumos da arqueologia brasileira.

\footnotetext{
Abstract: In this paper the author presents a general analysis on the direct analogy between material culture and ethnic identity in the Brazilian archaeology. It analyzes in a specific way the association among populations bearers of the Tupiguarani tradition, defined like this at that time of National Program of the Archaeological Researches (Pronapa, 1965-1970), and ethnic groups linguistically linked to the stock tupi. For those groups it has been attributed an identity or generic etnicidade of "guarani". This problem is discussed with
}

more depth by occasion of the appreciation of a judicial study on the Indigenous Land Sucuri'y, located in the municipal district of Maracaju, Mato Grosso do Sul State, Brazil. In the analyzed decision, the association between material culture and ethnic identity sends to the debate regarding the right to the land on the part of an indigenous community. During the elaborated study, the author questions the results ends of the expertise produced for the federal justice and it argues that evidences that sustain the thesis exist that that area is, in fact, traditionally busy for Kaiowá, in agreement with what it determines the Article 231, $\S 1^{\circ}$, of the Federal Constitution of 1988.

Key-words: Brazilian archaeology; ethnic identity; Kaiowá indians.

\section{Referências}

ALBERTI, V. História oral: a experiência do CPDOC. Rio de Janeiro: Fundação Getúlio Vargas/CPDO, 1990.

ALVES DA SILVA, C. \& EREMITES DE OLIVEIRA, J. Fontes textuais e etnoistória: possibilidades de novas abordagens para uma história indígena no estado do Tocantins. Revista do Museu Antropológico, Goiânia, 8(1), 2005. p. 77-84.

BARTH, F. Introduction. In: BARTH, F. (Ed.). Ethnic groups and boundaries: the social organization of culture difference. Bergen/Oslo, Universitetsforlaget; London, George Allen \& Unwin, 1969. p. 9-38.

Grupos étnicos e suas fronteiras. In: POUTIGNAT, P. \& STREIFF-FENART, J. Teorias $d a$ etnicidade. Seguido de Grupos étnicos e suas fronteiras de Fredrik Barth. Trad. de Élcio Fernandes. São Paulo: Editora Unesp, 1998. p. 185-227.

BECKER, I. R. B. Lideranças indígenas no começo das reduções jesuíticas da Província do Paraguay. Pesquisas, Série Antropologia, 47, 1992. p. 1-197.

BRAND, A. $O$ impacto da perda da terra sobre a tradição Kaiowá/Guarani: os difíceis caminhos da palavra. Porto Alegre, 1997. Tese (Doutorado em História)-PUCRS.

BROCHADO, J. J. J. P. An ecological model of the spread of pottery and Agriculture into Eastern South America. 1984. Tesis (PhD) - Urbana-Champaign, University of Ilinois at Urbana-Champaign.

CALDARELLI, S. B. (Org.). Atas do Simpósio sobre Política Nacional do Meio Ambiente e Patrimônio Cultural. Goiânia, IGPA-UCG/Fórum Interdisciplinar para o Avanço da Arqueologia, 1997.

Levantamento arqueológico em planejamento ambiental. Revista do Museu de Arqueologia e Etnologia (Série Suplemento), São Paulo, 3, 1999. p. 347-369. 
CARREIRA, E. A. Parecer do assistente técnico do Ministério Público Federal. In: Processo n. 97.08649. $1^{\text {a }}$ Vara da $1^{\text {a }}$ Seção Judiciária de Campo Grande/ MS, 2000. p.1366-1384.

CHAMORRO, G. Kurusu ñe'ëngatu: palabras que la historia no podría olvidar. Asunción: Universidad Católica, 1995.

A espiritualidade guarani: uma teologia ameríndia da palavra. São Leopoldo: Sinodal, 1998.

DUTRA, C. A. dos. Ofaié: morte e vida de um povo. Campo Grande: Instituto Histórico e Geográfico de Mato Grosso do Sul, 1996.

EREMITES DE OLIVEIRA, J. de \& PASTORE, I. Onde estão os sítios arqueológicos? Levantamento de antigos assentamentos kaiowá em Mato Grosso do Sul, Brasil. Programa e Resumos do VI Encontro de História de Mato Grosso do Sul. Dourados, ANPUH-MS, 2002. p. 68-69.

EREMITES DE OLIVEIRA, J. Los primeros pasos en dirección de una arqueología pantanera: de Max Schmidt y Branka Susnik hacia otras interpretaciones sobre los pueblos indígenas de las tierras bajas del Pantanal. Suplemento Antropológico, Asunción, 38(2), 2003a. p. 9-72.

Sobre os conceitos e as relações entre história indígena e etnoistória. Prosa, Campo Grande, 3(1), 2003b. p. 39-47.

FERREIRA, A. B. Os Corrêa, os Ponte, os Alves no planalto e serra de Maracajú: origem histórica, árvores genealógicas. Campo Grande: s./ed., 1993.

FERREIRA, F. B. \& ROSA, A. P. da. Maracaju e sua gente. Maracaju: s/ed., 1988.

FUNARI, P. P. A. et al. Introdução - A Primeira Reunião Internacional de Teoria Arqueológica na América do Sul: questões e debates. Revista do Museu de Arqueologia e Etnologia (Série Suplemento), São Paulo, 3, 1999. p. 1-12.

FUNARI, P. P. A. \& NOELLI, F. S. Pré-história do Brasil. São Paulo: Contexto, 2002.

JONES, S. The Archaeology of Ethnicity. Constructing identities in the past and present. London: Routledge, 1997.

KRIVOSHEINDECANESE, N.; ACOSTAALCARAZ, F. Ñe'ëryru. Diccionario Guaraní-Español Español-Guaraní. Asunción, Instituto Superior de Lengua/Universidad Nacional de Asunción, 1997.

LANDA, B. dos S. Os Ñandeva/Guarani e o uso do espaço na Terra Indígena Porto Lindo/Jakarey, município de Japorã/MS. Porto Alegre, 2005. Tese (Doutorado em História, Doutorado Internacional em Arqueologia) - PUCRS, 2v.
LA SALVIA, F. \& BROCHADO, J. P. Cerâmica guarani. Porto Alegre: Arte \& Cultura, 1989.

LIMA, T. A. Restos humanos e arqueologia histórica: uma questão de ética. Historical Archaeology in Latin America. Columbia: The University of South Carolina, v.6, 1994. p. 1-17.

MELIÀ, B. et al. Etnografía guaraní del Paraguay contemporáneo: los Pai-Tavyterã. Suplemento Antropológico, Asunción, 11(1-2), 1976. p. 151-295.

O Guarani: uma bibliografia etnológica. Santo Ângelo: Fundames, 1987.

MELIÀ, B. El pueblo Guaraní: unidad y fragmentos. Tellus, Campo Grande, 4(6), 2004. p. 151-162.

MOREIRADA SILVA, L. A legitimidade do processo de retomada das terras tradicionais pelos índios Kaiowá e Ñandeva em Mato Grosso do Sul. Brasília/ Dourados, 2002. Dissertação (Mestrado em Direito) - UnB/Unigran.

MURA, F. O tekoha como categoria histórica: elaborações culturais e estratégias kaiowa na construção do território. Fronteiras, 8(15), 2004. p. 109-143.

NEVES, W. A. A evolução do levantamento arqueológico na bacia do Alto Guapeí, SP. Revista de Préhistória, São Paulo, 6, 1984. p. 225-234.

. (Org.). Dossiê antes de Cabral: Arqueologia brasileira. Revista USP. São Paulo, 44(1-2), 1999/2000.

NOELLI, F. S. Sem tekohá não há teko: em busca de um modelo etnoarqueológico da aldeia e da subsistência guarani e sua aplicação a uma área de domínio no delta do rio Jacuí-RS. Porto Alegre, 1993. Dissertação (Mestrado) - PUCRS.

NOELLI, F. S. et al. Debate: hipóteses sobre a origem e a expansão dos Tupi. Revista de Antropologia, São Paulo, 39(2), 1996. p. 5-118.

NOELLI, F. S. A ocupação humana na região Sul do Brasil: Arqueologia, debates e perspectivas (18722000). Revista USP, São Paulo, 44(2), 1999/2000. p. 218-269.

ORSER JR., C. Introdução à arqueologia histórica . Trad. de P. P. A. Funari. Belo Horizonte: Oficina dos Livros, 1992.

PEREIRA, L. M. Parentesco e organização social kaiowá. Campinas, 1999. Dissertação (Mestrado em Antropologia) - Unicamp

. O movimento étnico-social pela demarcação das terras guarani em MS. Tellus, Campo Grande, 3(4), 2003. p. 137-145.

Imagens kaiowá do sistema social e seu entorno. São Paulo, 2004. Tese (Doutorado em Antropologia) - USP. 
RENFREW, C. \& BAHN, P. Arqueología: teorías, métodos y práctica. $2^{\mathrm{a}}$ ed. Trad. de M. J. M. Rial. Madrid: Akal, 1998.

SANTOS, J. A. M. dos. Relatório. Os Guarani do Trópico de Capricórnio. Identificação das áreas indígenas Cerrito, Vila Juty e Maracaju. Brasília: $2^{\mathrm{a}}$ Suer/Funai, 1986. [Mimeo.]

SANTOS, M. C. dos. Clastres e Susnik: uma tradução do "Guarani de papel”. In: GADELHA, R. A. F. (Ed.). Missões Guarani: impacto na socieade contemporânea. São Paulo: Educ/Fapesp, 1999. p. 205-219.

SCHADEN, E. Aspectos fundamentais da cultura guarani. 3. ed. São Paulo: Edusp, 1974.

SCHIAVETTO, S. N. de O. A arqueologia guarani: construção e desconstrução da identidade indígena. São Paulo: Annablume/Fapesp, 2003.

SOARES, A. L. R. Guarani: organização social e arqueologia. Porto Alegre: Edipucrs, 1997.
. Arqueologia, história e etnografia: o denominador guarani. Fronteiras, Campo Grande, 7(13), 2003. p. 31-62.

STEFANES PACHECO, R. A. Mobilizações guarani Kaiowá e Ñandeva e a (re)construção de territórios (1978-2003): novas perspectivas para o direito indígena. Dourados, 2004. Dissertação (Mestrado em História) - UFMS.

TENÓRIO, M. C. (Org.). Pré-história da Terra Brasilis. Rio de Janeiro: Editora UFRJ, 1999.

VIVEIROS DE CASTRO, E. B. Nimuendaju e os Guarani. In: NIMUENDAJU UNKEL, C. As lendas da criação e destruição do mundo como fundamentos da religião dos Apapocúva-Guarani. São Paulo, Hucitec/Edusp, 1987. p. xvii-xxxix.

VIVEIROS DE CASTRO, E. B. O nativo relativo. Mana, São Paulo, 8(1), 2002.p. 113-148. 